\title{
$\mathrm{HPLC}$ 를 이용한 의약품 주성분인 옥시라세탐의 Analytical Method Validation
}

\author{
김유곤` · 서홍석 · 원찬희 \\ 전북대학교 공과대학 환경공학과 \\ (2010. 10. 28. 접수, 2010. 12. 8. 승인)
}

\section{Analytical method validation of oxiracetam using HPLC}

\author{
Kim Yoo Gon ${ }^{\star}$, Seo Houng Seok and Won chan hee \\ Department of Environmental Engineering, Chonbuk National University 664-14, 1-ga, \\ Deokjin-dong, Deokjin-gu, Jeonju-city, Jeolabuk-do 561-756, Korea \\ (Received October 28, 2010; Accepted December 8, 2010)
}

\begin{abstract}
요 약: 완제품의 주성분인 옥시라세탐이 함유된 의약품의 시험법실시 계획서에 따른 시험이 적절히 진 행되었는지 시험법의 검증여부를 하고 본 protocol이 완제품 중 옥시라세탐의 정 량분석을 위한 HPLC 분 석법의 타당성을 검증하기 위한 문서화된 절차를 제공하는 것을 목적으로 한다. 본 실험에서는 옥시라세 탐 함량시험에 사용된 분석법에 대하여 시스템 적합성, 정밀성, 직선성, 범위, 정확도, 특이성, 정량한계, 검출한계에 대하여 확인하였다. 실험결과 시스템적합성에서 정밀도(RSD\%) $0.127 \%$ 이하, 이론단수 15081 , tailing factor 0.49 , 그리고 분리능 32.41 을 나타내었고, 정밀도실험에서는 RSD $\% 0.359 \%$ 이하의 결과를 보였다. 그리고 직선성 실험에서는 상관계수 $\left(\mathrm{R}^{2}\right)$ 가 1 을 나타내었고, 정확도 실험에서는 recovery test로서 최소 $98.4 \%$, 최대 $99.6 \%$ 로 기준을 만족하였다. 검출한계는 $0.1 \mathrm{mg} / \mathrm{L}$ 이였으며, 정량한계는 $0.5 \mathrm{mg} / \mathrm{L}$ 이었다. 그리고 특이성 실험에 있어서도 기준을 만족하는 결과를 나타내어 옥시라세탐을 주성분으로 하는 완제 의약품 시험법은 적합한 시험법임이 검증되었다.
\end{abstract}

\begin{abstract}
This study aims to determine that the test of medicines containing oxiracetam as their main ingredient was properly performed according to protocol. Furthermore, the study is to provide the written form of protocol in order to examine the validity of the HPLC analytical method for the quantitative analysis of oxiracetam in the finished products. In this experiment, system suitability, precision, linearity, range, accuracy, specificity, quantitative limit, and detection limit of the analytical method which was used to determine the contained quality of oxiracetam, were examined. The result shows that system suitability indicates $0.127 \%$ RSD, plate number 15081, tailing factor 0.49 , and resolution 32.41 . The experiment of precision reveals the result of below $0.359 \%$ for repetitiveness and among the subjects. In the linearity experiment, a coefficient of correlation $\left(R^{2}\right)$ indicates that it is 1 . The accuracy experiment satisfies the standards of the recovery test, which is minimum $98.4 \%$ and maximum $99.6 \%$. Detection
\end{abstract}

Corresponding author

Phone : +82-(0)10-8237-8239 Fax : +82-(0)33-251-3991

E-mail : kyg00789@hanmail.net 
limit is $0.1 \mathrm{mg} / \mathrm{L}$ and quantitative limit was found to be $0.5 \mathrm{mg} / \mathrm{L}$. The experiment to check the specificity also satisfies the standards, so the finished product using oxiracetam as the main ingredient is verified as suitable.

Key words: analytical method validation, HPLC, oxiracetam, system suitability

\section{1. 서 론}

본 실험의 목적은 의약품의 주성분인 옥시라세탐 시험법실시 계획서에 따른 시험이 적절히 진행되었는 지 결과를 확인하고 시험법의 검증여부를 확인한다.

본 Protocol은 의약품 중 옥시라세탐의 정량분석을 위한 HPLC 분석법의 타당성을 검증하기 위한 문서화 된 절차를 제공하는 것을 목적으로 한다.

\subsection{Validation의 개념}

GMP제도가 정착되면서 validation이란 용어가 자주 쓰이게 되었다. 이는 GMP 체제하의 의약품제조관리가 validation에 의하여 뒷받침되어야 하는데에 기인된다. 즉, 의약품의 품질보장은 최종제품의 시험성적만으로 이를 보장할 수 없으며, 원료선정에서부터 제품완성에 이르기까지 제조 전 과정에서의 품질변화 요인을 과학 적인 검증으로 validation이 뒷받침 되어야 하기 때문이 다. 그리하여, GMP의 운영, 관리는 물론 의약품의 허 가요건에도 validation이 영향을 주게 되었기 때문이다.

이와 같은 사실은 $\mathrm{GMP}$ 의 운영관리에 있어 관행에 따라 실시하였다는 사례의 예거나 설명만으로는 문제 에 대한 이해에 도움을 줄 수는 있어도, 해결을 위한 과학적인 입증이 될 수는 없기 때문이다. 이를 입증하 기 위하여서는 제품품질에 영향을 주는 요인이 되는 특정사항에 대하여, 구체적인 protocol을 작성하여, 이 에 따라 실시, 점검, 기록, 평가, 표준화한 문서화로 이를 입증할 수 있는 과학적인 검증의 제시가 필요하 게 되었기 때문이다. ${ }^{1,3}$

\section{2. 분석법 Validation의 필요성 및 시행 목적}

제조의 process validation이 과학적으로 실시되도록 하기 위해서는 이것을 확인, 검증하는 system인 시험, 검사가 과학적 근거에 바탕을 둔 타당성 있는 설비 및 방법으로 이루어지지 않으면 안 되며, 또한 신뢰성 있는 결론을 얻을 수 없다. 즉 시험, 검사에도 제조의 process validation과 동등 또는 그 이상의 validation이 필요하다. ${ }^{2}$
분석법의 개발 초기단계에서는 분석법의 신뢰성을 높이기 위해 주로 분석법의 변동원인을 검토하고, 개 발이 완료되고 표준화된 분석법 혹은 기존의 분석법 을 특정 시험법의 분석법으로서 채택하는 것인지의 여부 결정에는 시험법의 목적에 맞추어 주로 random 적 변동요인의 영향도 예상되는 작업을 시행한다. 시 험법에서 채택하고 있는 분석법을 수정하거나 의약품 의 제조방법을 변경할 경우 수정과 변경의 정도에 따 른 revalidation이 필요하게 된다. 한편 validate된 분석 법을 시험과 연구에서 routine하게 사용하는 경우에는 분석법이 validate된 상태로 유지되고 있다는 확인이 필요하다. 또한 분석법에서 사용되는 시약과 장치, 분 석자의 변경이 이루어진 경우에도 변경전후에서 분석 법이 일정하게 유지되고 있다는 보증을 얻기 위해 validation이 시행되고 있다. ${ }^{1,3}$

\subsection{Analytical Validation}

제품, 환경, 설비, 기기시험, 검사를 위한 시험, 검사 방법이 과학적인 근거, 타당성을 가지고 정하여져 있고 이것에 대한 validation이 확립되어 있지 않으면 안 된 다. 즉, 시험, 검사방법의 validation도 process validation 의 일환이고 그의 일부를 형성한다. 특이성은 공존이 예측되는 불순물, 분해물, 배합성분들이 서로 여향을 받지 않고 특이적으로 측정할 수 있는 능력이다. 직선 성은 측정법은 측정범위 내에 있어서 측정하는 특성 치와 측정치와의 사이에 직선관계가 있다는 것을 전 제로 하고 있다. 예를 들어 흡광도 측정법에 의한 정 량법의 경우 농도증가에 따라서 흡광도가 비례하여 증가하는 것을 증명해야 한다. 기 지량을 첨가한 시료 를 시험하여 증명한다. 정밀성은 재현성을 반복해서 분석할 때 재현성이 얼마나 좋으냐를 나타내는 것이 다. 다시 말해 분석 값이 평균치에 얼마나 집중되어 있느냐를 나타내는 것이며, 실제 측정 시에는 $\mathrm{n}$ 회 반 복 시험하여 얻은 결과의 표준편차를 확인하여 $2 \%$ 이내이면 적합한 것으로 본다. 표준편차가 크면 원인 을 알 수 없는 오차인 우연오차가 크다는 것을 말 해 준다. 매개정밀성은 동일 시료에 대해 다른 날짜, 다른 
시험자, 다른 설비 등의 실험실 변동이 미치는 변화를 확인하는 것이며, 표준편차 $2 \%$ 이내이면 적합한 것으 로 본다. 정확성과 회수율은 실제실험에 있어서의 정확 성은 동일검체에 대하여 동일한 방법으로 $\mathrm{n}$ 회 반복 시 험하여 그 평균치 $\mathrm{X}$ 를 계산할 때 $\mathrm{X}$ 가 실제 들어있는 물질의 양에 얼마나 접근하는지를 가지고 정확성을 알 수 있다. 통계적 처리는 실제 들어있는 표준치 $\mathrm{X}$ 와 측 정평균치 $\mathrm{X}(\mathrm{n}, \mathrm{s})(\mathrm{s}$; 표준편차) 사이의 차이에 대한 유의 성을 판정한다. 제제 중에 목적 성분을 정량할 때 공존 하는 성분에 의해 방해를 받을 수 있다. 확인방법은 정 량의 목적 성분을 추가하여 정량할 때 추가된 양이 정 확하게 회수되는 지로 입증한다. 견고성은 다소의 조건 변동이 주어지더라도 측정결과가 변동되지 않도록 설 정되어 있는가를 보는 것으로 검토한다. ${ }^{1-3}$

\section{2. 실 험}

\section{1. 실험장비 및 기구}

2.1.1. 장비 및 기구

HPLC system: Agilent HPLC(Agilent Technologies 1200series)

Column : Kromasil 100-10 $\mathrm{NH}_{2}$

Balance : Sartorius LE244S

Syringe filter:Millipore Millex-HV, Hydrophilic PVDF $0.45 \mu \mathrm{m}$

\subsubsection{HPLC기기조건}

검출기 : 자외부흡광도(파장 $220 \mathrm{~nm}$ )
이동상 : 아세토니트릴: 물(97:3)

유속 : $1.2 \mathrm{~mL} / \mathrm{min}$

주입량 : $20 \mu \mathrm{L}$

2.1.3. 시약 및 용매

Acetonitrile, HPLC grade

Water, HPLC grade

\subsection{4. 표준품}

표준품명 : 옥시라세탐(Oxiracetam) (99.81\%)

내부표준품명 : 무수카페인(Caffeine anhydrous) $(100.3 \%)$

\subsection{5. 시험용액제조}

내부표준용액 : 무수카페인 $50 \mathrm{mg}$ 을 이동상에 녹여 $50 \mathrm{~mL}$ 메스프라스크에 채움

표준액 : 옥시라세탐 표준품 $50 \mathrm{mg}$ 을 $50 \mathrm{~mL}$ 메스플 라스크에 넣고 물 $5 \mathrm{~mL}$ 를 넣어 녹인 후 아세토니트 릴 $40 \mathrm{~mL}$ 와 내분표준용액 $1 \mathrm{~mL}$ 를 넣은 후 이동상으 로 표선을 맞춤

검액 : 20 정 이상을 취해 무게를 단 후 가루로 분쇄, 해당량 $50 \mathrm{mg}$ 을 취해 물 $5 \mathrm{~mL}$ 로 녹인 후 표준액 제 조방법과 동일한 방법으로 제조

\section{2. 실험방법 및 결과}

\subsubsection{System Suitability Test}

$50 \mathrm{~mL}$ 메스플라스크에 옥시라세탐 표준품 $50 \mathrm{mg}$ 을 넣고 물 $5 \mathrm{~mL}$ 로 녹인후 아세토니트릴 $40 \mathrm{~mL}$ 와

Table 1. Result of system suitability test about retention time, peak area, tailing factor, plate number and resolution

\begin{tabular}{cccccccc}
\hline \hline 1 & $\begin{array}{c}\text { Retention } \\
\text { time(IS) }\end{array}$ & $\begin{array}{c}\text { Retention } \\
\text { time }\end{array}$ & $\begin{array}{c}\text { Peak Area } \\
\text { (IS) }\end{array}$ & Peak Area & Tailing factor & Plate number & Resolution \\
2 & 2.917 & 9.410 & 827.48846 & 4412.38916 & 0.49 & 15140 & 32.49 \\
3 & 2.918 & 9.410 & 828.93701 & 4423.33301 & 0.49 & 15139 & 32.48 \\
4 & 2.918 & 9.409 & 828.03546 & 4420.19922 & 0.49 & 15136 & 32.48 \\
5 & 2.918 & 9.406 & 829.33813 & 4415.69287 & 0.49 & 15129 & 32.47 \\
6 & 2.919 & 9.405 & 828.54608 & 4425.03027 & 0.49 & 15125 & 32.46 \\
7 & 2.920 & 9.406 & 828.59583 & 4428.35059 & 0.49 & 15128 & 32.36 \\
8 & 2.918 & 9.410 & 829.36572 & 4424.05127 & 0.49 & 15140 & 32.38 \\
9 & 2.917 & 9.414 & 828.98834 & 4427.77686 & 0.49 & 15152 & 32.41 \\
10 & 2.912 & 9.409 & 829.09406 & 4430.33643 & 0.49 & 14592 & 32.06 \\
Average & 2.910 & 9.408 & 829.56915 & 4421.84619 & 0.49 & 15133 & 32.51 \\
RSD\% & 2.917 & 9.409 & 828.79600 & 4422.90059 & 0.49 & 15081 & 32.41 \\
\hline \multirow{2}{*}{ Criteria } & 0.108 & 0.028 & 0.078 & 0.127 & - & - & - \\
\hline
\end{tabular}


내부표준액 $1 \mathrm{~mL}$ 를 넣어 녹인 후 이동상으로 표선 맞추어 제조한 시험용액을 6 회 반복 실험하여 ${ }^{9}$ 다음 항목, Peak area RSD (\%) $1.0 \%$ 이하, RT RSD (\%) $1.0 \%$ 이하, 최저이론단수(N) 2000 이상, Tailing factor (T) 2.0 이하, Resolution (R) 1.5 이상을 만족하는지를 실험 하였다. 실험결과 Table 1.에서 보듯이 Peak area $\mathrm{RSD} \%$ 는 $0.078 \%$ (I.S), $0.127 \%$ 의 결과를 나타내었고, RT RSD (\%)는 $0.108 \%$ (I.S), $0.028 \%$, 최저이론단수 $(\mathrm{N})$ 는 15081.4, Tailing factor $(\mathrm{T})$ 는 0.49 , Resolution (R)은 32.410 로 상기의 기준을 모두 만족하는 결과를 나타내었다.

\subsubsection{Precision}

상기 실험용액제조방법으로 제조한 표준용액과 내 부표준액은 10 회 반복 분석하여 표준액은 R.T와 Area 의 $\mathrm{RSD}(\%)$ 가 $1.0 \%$ 이하를 만족하는지와 검액에서는 검액 6 개를 각 3 회식 반복 주입하여 검액 6 개의 함량 값 $\mathrm{RSD}(\%) 2.0 \%$ 이하일 때 만족하는 것으로 판정하 였으며, ${ }^{9,10}$ 실험자간 결과 비교는 표준액, 검액 6 개 각 3 회씩 반복 주입하여 기준에 적합여부를 확인 하였다. 실험결과 Table 1에 나타난 것처럼 표준액 R.T RSD (\%) 는 $0.028-0.108 \%$, Area RSD (\%)는 0.078 0.127\%로 만 족하는 결과를 보였고, 검액 6 개의 표준액 반복실험에 서(Table 2) 피크면적 RSD (\%) 0.063 0.151\%, 내부표 준액 $\mathrm{RSD}(\%) \quad 0.0240 .107 \%$ 의 결과를 나타내었다. 그리고 시험자간 비교실험에서(Table 3, 4)는 표준액 피크면적 $\mathrm{RSD}(\%)$ 는 $0.135 \%$, 내부표준액 피크면적 $\mathrm{RSD}(\%)$ 는 $0.158 \%$, 검액 6 개의 대한 표준액 반복실 험에서 피크면적 $\mathrm{RSD}(\%)$ 는 0.098 $0.326 \%$, 내부표준 액 피크면적 반복실험에서는 $\mathrm{RSD}(\%)$ 는 0.007 0.109\%
Table 3. Experimental result of person-to-person variability about each 3 repetitive injection in standard solution and internal standard solution

\begin{tabular}{lcc}
\hline & $\begin{array}{c}\text { I.S Solution Peak } \\
\text { Area }\end{array}$ & $\begin{array}{c}\text { STD Solution Peak } \\
\text { Area }\end{array}$ \\
\hline 1st & 831.52106 & 4419.57617 \\
2nd & 829.70605 & 4409.72168 \\
3rd & 828.96887 & 4408.75000 \\
Average & 830.06533 & 4412.68262 \\
RSD(\%) & 0.158 & 0.135 \\
\hline
\end{tabular}

로 결과를 모두 만족하였다.

\subsubsection{Linearity \& Range}

이 실험기준은 Linearity-상관계수(r) 0.99 이상, Range - 허가범위(95.0 105.0\%) 포함 하여야 한다.,5 표준원 액 제조는 표준품 $500 \mathrm{mg}$ 을 $100 \mathrm{~mL}$ 메스플라스크에 넣은 후 물 $10 \mathrm{~mL}$ 로 넣어 녹이고 아세토니트릴 80 $\mathrm{mL}$ 넣어 녹인 후 이동상으로 표선을 맞춤. 표준용액 은 $50 \mathrm{~mL}$ 메스플라스크에 표준원액 각각 $8 \mathrm{~mL}, 9$ $\mathrm{mL}, 10 \mathrm{~mL}, 11 \mathrm{~mL}, 12 \mathrm{~mL}$ 를 넣을 후 아세토니트릴 $40 \mathrm{~mL}$ 와 내부표준액 $1 \mathrm{~mL}$ 를 넣어 용해 후 이동상으 로 표선을 맞추어 제조농도는 각각 $800,900,1000$, $1100,1200 \mathrm{mg} / \mathrm{L}$ 이 되었다. 기준은 Linearity 상관계 수 $\left(\mathrm{R}^{2}\right)$ 0.99이상, Range 허가범 위(95.0 105.0\%)이며 이 허가범위를 포함하여야 한다. 실험결과 data는 직 선성 표준액 중 내부표준물질에 대한 옥시라세탐의 면적비로 환산하였다. 실험결과 Linearity 상관계수 $\left(\mathrm{R}^{2}\right)$ 은 1 로 나타나 직선성에서는 좋은 결과를 나타내 었다.

Table 2. Experimental result of each 3 repetitive injection of 6 sample solution

[Criteria : RSD\% Max 2\%]

\begin{tabular}{lrrrrrr}
\hline \hline 1st & \multicolumn{1}{c}{ Sample 1 } & Sample 2 & \multicolumn{1}{c}{ Sample 3 } & \multicolumn{1}{c}{ Sample 4 } & \multicolumn{1}{c}{ Sample 5 } & Sample 6 \\
2nd & 4414.41504 & 4408.36816 & 4418.75049 & 4431.09717 & 4402.77100 & 4415.39453 \\
3rd & 4410.12061 & 4399.31885 & 4430.30127 & 4423.72852 & 4400.64404 & 4418.40332 \\
Average & 4415.68311 & 4411.24609 & 4418.71826 & 4424.46191 & 4396.45508 & 4420.99707 \\
RSD\% & 4413.40625 & 4406.31103 & 4422.59001 & 4426.42920 & 4399.95671 & 4418.26497 \\
1st(IS) & 8.066 & 0.141 & 0.151 & 0.092 & 0.073 & 0.063 \\
2nd(IS) & 833.95502 & 835.55341 & 833.45209 & 834.45624 & 835.08923 & 836.55652 \\
3rd(IS) & 834.18048 & 835.55402 & 833.09344 & 832.67200 & 836.03491 & 834.83813 \\
Average & 833.86642 & 835.35602 & 833.32682 & 833.58620 & 835.54354 & 835.67248 \\
RSD\% & 0.044 & 0.041 & 0.024 & 0.107 & 0.057 & 0.103 \\
Assay\% & 98.60 & 98.64 & 99.44 & 98.73 & 98.10 & 98.87 \\
\hline
\end{tabular}


Table 4. Experimental result of person-to-person variability about each 3 repetitive injection of 6 sample solution

[Criteria : RSD\% Max 2\%]

\begin{tabular}{lrrrrrr}
\hline \hline & \multicolumn{1}{c}{ Sample 1 } & \multicolumn{1}{c}{ Sample 2 } & \multicolumn{1}{c}{ Sample 3 } & \multicolumn{1}{c}{ Sample 4 } & \multicolumn{1}{c}{ Sample 5 } & \multicolumn{1}{c}{ Sample 6 } \\
\hline 1st & 4408.83398 & 4401.08740 & 4443.69092 & 4408.05762 & 4399.64258 & 4437.29248 \\
2nd & 4424.48438 & 4385.63818 & 4435.83643 & 4402.94873 & 4407.64209 & 4429.74609 \\
3rd & 4405.54541 & 4391.74170 & 4433.20410 & 4432.62598 & 4379.77637 & 4437.32178 \\
average & 4412.95459 & 4392.82243 & 4437.57715 & 4414.54411 & 4395.68701 & 4434.78678 \\
RSD\% & 0.229 & 0.177 & 0.123 & 0.359 & 0.326 & 0.098 \\
1st(I.S) & 833.52405 & 834.50043 & 837.93817 & 835.51172 & 836.77063 & 836.81622 \\
2nd(I.S) & 834.47906 & 832.94476 & 838.03009 & 834.67303 & 836.85797 & 836.37457 \\
3rd(I.S) & 833.50439 & 834.53827 & 838.03741 & 835.42004 & 836.60889 & 836.16534 \\
Average & 833.83583 & 833.99449 & 838.00189 & 835.20160 & 836.74583 & 836.45204 \\
RSD\% & 0.0669 & 0.109 & 0.007 & 0.055 & 0.015 & 0.040 \\
Assay\% & 99.35 & 98.68 & 99.02 & 99.03 & 98.61 & 98.95 \\
\hline
\end{tabular}

Table 5. Experimental result of OXIRACETAM peak area in standard solution.

\begin{tabular}{lrrrrr}
\hline \hline Conc. $(\mathrm{mg} / \mathrm{L})$ & \multicolumn{1}{c}{800} & \multicolumn{1}{c}{900} & 1000 & \multicolumn{1}{c}{1100} & 1200 \\
\hline & 3548.68652 & 3986.74927 & 4441.60400 & 4846.66895 & 5312.76855 \\
STD Peak Area & 3535.23413 & 3992.07568 & 4464.48340 & 4850.23096 & 5289.54443 \\
& 3540.35278 & 3984.15649 & 4423.84424 & 4865.08130 & 5295.18896 \\
\hline Average & 3541.42448 & 3987.66048 & 4443.31055 & 4853.99374 & 5299.16731 \\
RSD $(\%)$ & 0.192 & 0.101 & 0.459 & 0.201 & 0.229 \\
\hline
\end{tabular}

Table 6. Experimental result of internal standard peak area in standard solution

\begin{tabular}{lrrrrr}
\hline \hline Conc. $(\mathrm{mg} / \mathrm{L})$ & \multicolumn{1}{c}{800} & \multicolumn{1}{c}{900} & \multicolumn{1}{c}{1000} & \multicolumn{1}{c}{1100} & 1200 \\
\hline & 833.73962 & 829.33960 & 834.50336 & 829.46411 & 831.18719 \\
I.S Peak Area & 832.48553 & 828.62006 & 832.30219 & 829.41412 & 830.38934 \\
& 832.59479 & 829.85303 & 833.06049 & 828.08130 & 831.00244 \\
\hline Average & 832.94000 & 829.27090 & 833.28868 & 828.98651 & 893.37878 \\
RSD(\%) & 0.083 & 0.075 & 0.134 & 0.095 & 0.040 \\
\hline
\end{tabular}

\subsubsection{Accuracy}

실험방법은 위약 $2 \mathrm{mg}$ 과 옥시라세탐 표준품 각각 $40 \mathrm{mg}, 50 \mathrm{mg}, 60 \mathrm{mg}$ 을 $50 \mathrm{~mL}$ 메스플라스크에 넣고 물 $5 \mathrm{~mL}$ 로 녹인 후 아세토니트릴 $40 \mathrm{~mL}$ 와 내부표준 액 $1 \mathrm{~mL}$ 를 넣어 녹인 후 이동상으로 표선을 맞추어 제조하였다. 실험결과는 회수율로서 평가하였으며, 7,8 얻어지는 평균값과 참값의 편차가 $3.0 \%$ 이내일 경우 적합으로 판정하였고, 실험결과 98.85 99.57\%로 적합 한 결과를 나타내었다.

\subsubsection{Quantitation Limit \& Detection Limit ${ }^{5,6}$}

표준액 제조방법은 옥시라세탐 표준품 $50 \mathrm{mg}$ 을 50 $\mathrm{mL}$ 메스플라스크에 넣어 물 $5 \mathrm{~mL}$ 를 넣어 녹이고 아 세토니트릴 $40 \mathrm{~mL}$ 와 내부표준액 $1 \mathrm{~mL}$ 를 넣어 녹인 후 이동상으로 표선을 맞추었다. $\mathrm{QL}, \mathrm{DL}$ 표준액은 표
Table 7. OXIRACETAM peak area/internal standard peak area ratio in standard solution

\begin{tabular}{clllll}
\hline \hline $\begin{array}{c}\text { Conc. } \\
(\mathrm{mg} / \mathrm{L})\end{array}$ & 800 & 900 & 1000 & 1100 & 1200 \\
\hline Area ratio & 4.26 & 4.81 & 5.32 & 5.84 & 6.39 \\
$(\mathrm{STD} / \mathrm{I} . \mathrm{S})$ & 4.25 & 4.82 & 5.36 & 5.85 & 6.37 \\
& 4.25 & 4.80 & 5.31 & 5.88 & 6.37 \\
\hline Average & 4.25 & 4.81 & 5.33 & 5.86 & 6.38 \\
RSD $(\%)$ & 0.136 & 0.208 & 0.496 & 0.355 & 0.181 \\
\hline
\end{tabular}

준액 $(1000 \mathrm{mg} / \mathrm{L}) 1 \mathrm{~mL}$ 를 $100 \mathrm{~mL}$ 메스플라스크에 넣 은 후 이 용액을 $1 \mathrm{~mL}, 5 \mathrm{~mL}, 10 \mathrm{~mL}$ 를 취하여 각각 $0.1 \mathrm{mg} / \mathrm{L}, 0.5 \mathrm{mg} / \mathrm{L}, 10 \mathrm{mg} / \mathrm{L}$ 이 되도록 제조하였다. 검출한계는 $\mathrm{S} / \mathrm{N}$ 비를 3 이상, 정량한계를 $\mathrm{S} / \mathrm{N}$ 비를 10 이 상일 때를 적정 조건으로 설정하였다. 그리고 용매피 크의 높이의 평균값으로 각각 분석한 개별 data를 나 
Calibration curve

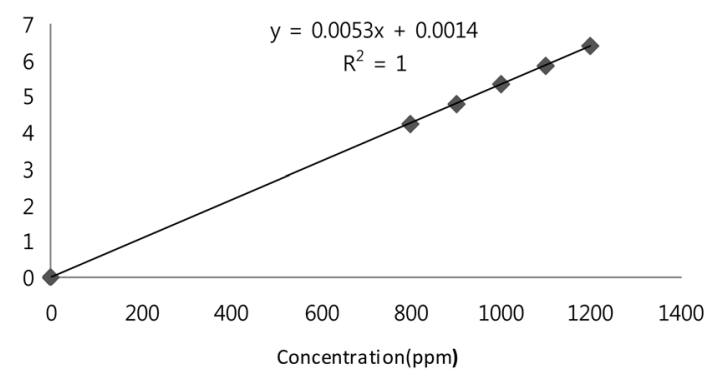

Fig. 1. Standard calibration curve of OXIRACETAM.

눈 값으로 $\mathrm{S} / \mathrm{N}$ 비를 산출 하였다.

실험결과 검출한계 농도는 $0.1 \mathrm{mg} / \mathrm{L}$ 으로 설정되었 으며, 정량한계는 $0.5 \mathrm{mg} / \mathrm{L}$ 으로 설정 되었다.

\subsubsection{Specificity}

위약 $2 \mathrm{mg}$ 을 $50 \mathrm{~mL}$ 메스플라스크에 넣어 $5 \mathrm{~mL}$ 물 을 넣어 녹인 후 아세토니트릴 $40 \mathrm{~mL}$, 내부표준액 1 $\mathrm{mL}$ 를 넣어 녹이고 이동상으로 표선을 맞추어 검액으 로 하였다. 정밀도 실험의 검액과 정확도 실험의 검액 에서 분석된 분석물질 peak 유지시간이 일치하고 '위 약의 조제'에서 조제된 위약의 분석물질에서는 위와 같은 시간대에 일치하는 peak가 없을 때 특이성이 확 인되었다고 한다. 실험결과 같은 시간대에 peak가 나 타나지 않아 특이성이 확인됨을 알 수 있었다.

\subsection{7. 실험결과}

본 실험결과 시스템적합성에서 피크면적과 R.T의 정 밀도(RSD\%) $0.13 \%$ 이하, 이론단수 15081 , Tailing

Table 8. Experimental result of accuracy test

\begin{tabular}{|c|c|c|c|c|c|c|c|}
\hline $\begin{array}{l}\text { Placebo } \\
\text { (mg) }\end{array}$ & $\begin{array}{l}\text { STD } \\
(\mathrm{mg})\end{array}$ & I.S Peak area & $\begin{array}{c}\text { I.S Peak area } \\
\text { average }\end{array}$ & Real data & $\begin{array}{l}\text { Real data } \\
\text { average }\end{array}$ & $\begin{array}{c}\text { Real data } \\
\text { average/I.S Peak } \\
\text { area average }\end{array}$ & $\begin{array}{l}\text { Criteria } \\
: 100 \pm 3.0 \%\end{array}$ \\
\hline 2.1 & 40.1 & $\begin{array}{l}839.68750 \\
839.57245 \\
839.59644\end{array}$ & 839.61880 & $\begin{array}{l}3562.28809 \\
3559.50806 \\
3564.32080\end{array}$ & 3562.03898 & 4.24245 & 99.32 \\
\hline 2.0 & 40.0 & $\begin{array}{l}838.98242 \\
838.32031 \\
837.89734\end{array}$ & 838.40002 & $\begin{array}{l}3561.44580 \\
3553.65015 \\
3555.88135\end{array}$ & 3556.99243 & 4.24260 & 99.57 \\
\hline 2.1 & 40.0 & $\begin{array}{l}839.71423 \\
840.94250 \\
840.35907\end{array}$ & 840.33860 & $\begin{array}{l}3498.21338 \\
3531.90918 \\
3536.42139\end{array}$ & 3522.18132 & 4.19138 & 98.37 \\
\hline 2.2 & 50.1 & $\begin{array}{l}834.37616 \\
835.14478 \\
835.58862\end{array}$ & 835.03652 & $\begin{array}{l}4440.47266 \\
4420.11084 \\
4413.58691\end{array}$ & 4424.72347 & 5.29884 & 99.29 \\
\hline 2.0 & 50.0 & $\begin{array}{l}839.97607 \\
839.06403 \\
839.07190\end{array}$ & 839.37067 & $\begin{array}{l}4437.04199 \\
4441.32959 \\
4446.43457\end{array}$ & 4441.60205 & 5.29159 & 99.36 \\
\hline 2.1 & 50.1 & $\begin{array}{l}836.98944 \\
835.89374 \\
835.61383\end{array}$ & 836.16567 & $\begin{array}{l}4443.35498 \\
4441.12744 \\
4435.05371\end{array}$ & 4439.84538 & 5.30977 & 99.50 \\
\hline 2.3 & 60.2 & $\begin{array}{l}839.97394 \\
838.13745 \\
839.57526\end{array}$ & 839.22888 & $\begin{array}{l}5322.42090 \\
5324.70166 \\
5312.02686\end{array}$ & 5319.71647 & 6.33881 & 98.85 \\
\hline 2.1 & 60.0 & $\begin{array}{l}837.47016 \\
839.64514 \\
836.99731\end{array}$ & 838.03754 & $\begin{array}{l}5307.77539 \\
5360.10937 \\
5309.50781\end{array}$ & 5325.79752 & 6.35508 & 99.44 \\
\hline 2.0 & 60.3 & $\begin{array}{l}838.02069 \\
835.84271 \\
836.20685\end{array}$ & 836.69008 & $\begin{array}{l}5293.42188 \\
5311.80273 \\
5323.70654\end{array}$ & 5309.64372 & 6.34601 & 98.80 \\
\hline
\end{tabular}


Table 9. Experimental result of Quantitation Limit \& Detection Limit

\begin{tabular}{lccl}
\hline \multicolumn{1}{c}{ Sample } & Peak Height & $\mathrm{S} / \mathrm{N}$ & \\
\hline Solvent-1 & 0.005305 & & \\
Solvent-2 & 0.010703 & & \\
Solvent-3 & 0.009624 & & \\
$0.1 \mathrm{mg} / \mathrm{L}-1$ & 0.044982 & 5.3 & \\
$0.1 \mathrm{mg} / \mathrm{L}-2$ & 0.066400 & 7.8 & Detection Limit \\
$0.1 \mathrm{mg} / \mathrm{L}-3$ & 0.068991 & 8.1 & \\
$0.5 \mathrm{mg} / \mathrm{L}-1$ & 0.217021 & 25.4 & \\
$0.5 \mathrm{mg} / \mathrm{L}-2$ & 0.202190 & 23.7 & Quantitation Limit \\
$0.5 \mathrm{mg} / \mathrm{L}-3$ & 0.183604 & 21.5 & \\
$1 \mathrm{mg} / \mathrm{L}-1$ & 0.356734 & 41.8 & \\
$1 \mathrm{mg} / \mathrm{L}-2$ & 0.344515 & 40.3 & \\
$1 \mathrm{mg} / \mathrm{L}-3$ & 0.350157 & 41.0 & \\
\hline
\end{tabular}

factor 0.49 , 그리고 분리능 32.41을 나타내었고, 정 밀도실험 중 반복실험의 $\mathrm{RSD} \% \quad 0.27 \sim 0.44 \%, \mathrm{R} . \mathrm{T}$ 와 시험자간실험에서 각각 $0.11 \%, 0.36 \%$ 의 결과를 보 였다. 그리고 직선성 실험에서는 상관계수 $\left(\mathrm{R}^{2}\right)$ 가 1 을 나타내었고 범위에서도 기준범위를 만족하는 결과를 나타내었으며, 정확도 실험에서는 Recovery test로서 최소 $98.4 \%$, 최대 $99.6 \%$ 로 기준을 만족하였다. 검출 한계를 $\mathrm{S} / \mathrm{N}$ 3이상을 만족하는 농도로 $0.1 \mathrm{mg} / \mathrm{L}$ 이였 으며, 정량한계는 $\mathrm{S} / \mathrm{N} 10$ 이상을 만족하는 $0.5 \mathrm{mg} / \mathrm{L}$
이었다. 그리고 특이성 실험에 있어서도 표준품과 내부표준물의 피크가 나타나는 시간대에 다른 피크 들이 나타나지 않아 기준을 만족하는 결과를 나타내 었다.

\section{3. 결 론}

본 실험결과 시스템적합성에서 정밀도(RSD\%) $0.13 \%$ 이하, 이론단수 15081 , Tailing factor 0.49 , 그 리고 분리능 32.41 을 나타내었고, 정밀도실험에서는 반복성의 시험자간실험에서 각각 $0.2 \%, 0.4 \%$ 의 결 과를 보였다. 그리고 직선성 실험에서는 상관계수 $\left(\mathrm{R}^{2}\right)$ 가 1 을 나타내었고 범위에서도 기준범위를 만족 하였고, 정확도 실험에서는 Recovery test로서 최소 $98.4 \%$, 최대 $99.6 \%$ 로 기준을 만족하였다. 검출한계 는 $0.1 \mathrm{mg} / \mathrm{L}$ 이였으며, 정량한는 $0.5 \mathrm{mg} / \mathrm{L}$ 이었다. 그 리고 특이성 실험에 있어서도 기준을 만족하는 결과 를 나타내었다.

완제의약품의 주원료인 옥시라세탐 함량시험에 사 용된 분석법에 대하여 시스템 적합성, 정밀성, 직선 성, 범위, 정확도, 특이성, 정량한계, 검출한계에 대 하여 확인 하였다. 따라서 옥시라세탐을 주성분으로 하는 완제의약품 시험법은 적합한 시험임이 검증되 었다.

Table 10. The result table of the this experiment

\begin{tabular}{|c|c|c|c|c|c|}
\hline & Item & & Acceptance Criteria & Result & Conclusion \\
\hline \multirow{5}{*}{$\begin{array}{l}\text { System } \\
\text { Suitability } \\
\text { Test }\end{array}$} & \multirow{2}{*}{ Precision } & Peak area & $\mathrm{RSD} \leq 1.0 \%$ & $0.13 \%$ & Satisfaction \\
\hline & & RT & $\mathrm{RSD} \leq 1.0 \%$ & $0.11 \%$ & Satisfaction \\
\hline & \multirow{3}{*}{\multicolumn{2}{|c|}{$\begin{array}{c}\text { Plate number } \\
\text { Tailing factor (symmetry factor) } \\
\text { Resolution }\end{array}$}} & $\mathrm{N} \geq 2000$ & 15081 & Satisfaction \\
\hline & & & $\mathrm{T} \leq 2.0$ & 0.49 & Satisfaction \\
\hline & & & $\mathrm{R} \geq 1.5$ & 32.41 & Satisfaction \\
\hline \multirow{3}{*}{ Precision } & \multirow[t]{2}{*}{ Repeatability } & Assay & $\mathrm{RSD} \leq 2.0 \%$ & $\begin{array}{l}\text { Person1 } 0.44 \% \\
\text { Person2 } 0.27 \%\end{array}$ & Satisfaction \\
\hline & & RT & $\mathrm{RSD} \leq 1.0 \%$ & $0.11 \%$ & Satisfaction \\
\hline & $\begin{array}{l}\text { Intermediate } \\
\text { precision }\end{array}$ & Person & $\begin{array}{l}\text { Person to person assay } \\
\mathrm{RSD} \leq 2.0 \%\end{array}$ & $0.36 \%$ & Satisfaction \\
\hline \multicolumn{3}{|c|}{ Linearity } & $\mathrm{R}^{2} \geq 0.99$ & 1.00 & Satisfaction \\
\hline \multicolumn{3}{|c|}{ Range } & $\begin{array}{l}\text { range inclusion } \\
(95.0 \sim 105.0 \%)\end{array}$ & $80.0 \sim 120.0 \%$ & Satisfaction \\
\hline \multicolumn{3}{|c|}{ Accuracy } & $\begin{array}{l}\text { Average Recovery } \\
100.0 \pm 3.0 \%\end{array}$ & $\begin{array}{l}\text { Min. 98.4\% } \\
\text { Max. 99.6\% }\end{array}$ & Satisfaction \\
\hline \multicolumn{3}{|c|}{ Quantitation Limit } & Signal/noise $\geq 10$ & $0.1 \mathrm{ppm}$ & Satisfaction \\
\hline \multicolumn{3}{|c|}{ Detection Limit } & Signal/noise $\geq 3$ & $0.5 \mathrm{ppm}$ & Satisfaction \\
\hline \multicolumn{3}{|c|}{ Specificity } & Not detection & Satisfaction & Satisfaction \\
\hline
\end{tabular}




\section{참고문헌}

1. 식약청, 의약품등 밸리데이션 실시에 관한 규정”, 식 품의약품안전청고시 제2009-173호.

2. 식약청, "의약품 등 기준 및 시험방법 심사의뢰서 심 사규정”, 식품의약품안전청고시 제2006-56호.

3. 대한약전 제 9 개정, “의약품등 분석법 밸리데이션에 대한 지침", 1366.

4. Alison E. Bretnall and Graham S. Clarke, Validation of Analytical Test Methods, Separation Sci. Tech., 10(11), 429-457(2011).

5. G. S. Clarke, The validation of analytical methods for drug substances and drug products in UK pharmaceutical laboratories, J. Pharm. Biomed. Anal., 12(5), 643652(1994).

6. Johan Lindholm, Monika Johansson, Torgny Fornstedt, Guidelines for analytical method development and validation of biotechnological synthesis of drugs: Production of a hydroxyprogesterone as model, J. Chro- matogr. B, 791(1-2), 323-336(2003).

7. Eric Rozet, Attilio Ceccato, Cdric Hubert, Eric Ziemons, Radu Oprean, Serge Rudaz, Bruno Boulanger, Philippe Hubert, Analysis of recent pharmaceutical regulatory documents on analytical method validation, $J$. Chromatogr. A, 1158(1-2), 111-125(2007).

8. ISO/IEC 17025, General requirements for the competence of testing and calibration laboratories, JIS $Q$ 17025-2000(1999).

9. J. W. Collier, R. B. Shah, A. R. Bryant, M. J. Habib, M. A. Khan and P. J. Faustino, Development and application of a validated HPLC method for the analysis of dissolution samples of levothyroxine sodium drug products, J. Pharm. Biomed. Anal. (2010).

10. VAndreas S. L. Mendez, Martin Steppe and Elfrides E. S. Schapoval, Validation of HPLC and UV spectrophotometric methods for the determination of meropenem in pharmaceutical dosage, J. Pharm. Biomed. Anal., 33(5), 947-954(2003). 